\title{
Antimicrobial Activity of the DNA Minor Groove Binders Furamidine and Analogs
}

\author{
David W. Boykin \\ Department of Chemistry, Georgia State University, Atlanta, GA, 30303-3088, USA
}

\begin{abstract}
Análogos arílicos de diamidinas da pentamidina e do berenil que interagem com a fenda menor de DNA estão sendo sintetizados com amplo espectro de atividade antimicrobiana. Várias séries de análogos da furamidina, 1,5-bis[4-amidinofenil]furano foram descritas e apresentaram boa potência quando administradas de forma intravenosa. Entretanto, elas foram inativas quando administradas oralmente. As pró-drogas do tipo amidoxima e carbamato dessas furamidinas são potentes quando administradas oralmente. Atualmente uma dessas pró-drogas, a bis- $O$-metiloxima está em estudos clínicos de Fase II.
\end{abstract}

Aryl diamidine analogs of pentamidine and berenil that bind to the minor groove of DNA have been developed which show broad spectrum antimicrobial activity. Several series of analogs of 2,5bis[4-amidinophenyl]furan (furamidine) have been described which are quite effective when given intravenously, however they are ineffective on oral administration. Amidoxime and carbamate prodrugs of furamidine are quite effective when given orally. One of these prodrugs, a bis- $O$-methylamidoxime is currently in Phase II clinical trials.

Keywords: furamidines, prodrugs, DNA minor groove binders

\section{Introduction}

Pentamidine(1) and berenil(2) are aromatic diamidines that are known to bind to the DNA minor groove at AT tracts $^{1-4}$ and to have a long history as antimicrobial agents. ${ }^{5}$ These molecules may be viewed as benzamidines connected by acyclic linkers. In the 1930's these type diamidine molecules were studied for their use against African trypanosomes. ${ }^{6,7}$ A large number of synthetic aromatic diamidines which may be viewed as derived from $\mathbf{1}$ and $\mathbf{2}$ have demonstrated broad spectrum antimicrobial activity against several protozoan and fungal infections. ${ }^{8}$
At present, for this diamidine class of compounds only pentamidine has been found to have significant clinical use. Currently, pentamidine is used against primary stage African trypanosomiasis, antimony-resistant leishmaniasis and AIDs associated Pneumocystis carinii. ${ }^{9-11}$ Pentamidine is not effective when given orally and several toxic effects including hypotension, dysglycemia, and renal and hepatic toxicity have been reported. ${ }^{12-14}$ Some of the toxicity of pentamidine has been attributed to its metabolism involving cleavage of the linker. ${ }^{15}$

In an effort to develop aromatic diamidines with improved properties we have studied analogs in which the<smiles>N=C(N)c1ccc(OCCCCCOc2ccc(C(=N)N)cc2)cc1</smiles><smiles>N=C(N)c1ccc(N=NNc2ccc(C(=N)N)cc2)cc1</smiles><smiles>N=C(N)c1ccc(-c2ccc(-c3ccc(C(=N)N)cc3)o2)cc1</smiles>

* e-mail: dboykin@gsu.edu 
acyclic linkers of $\mathbf{1}$ and $\mathbf{2}$ have been replaced by heterocyclic rings. Sometime ago it was reported that 2,5bis[4-amidinophenyl]furan (3,furamidine) was effective against trypanosomes in both murine and simian models. ${ }^{16,17}$ More recently furamidine was found to be highly active in animal models for Pneumocystis carinii and Cryptosporidium parvum. ${ }^{18,19}$ Extensive biophysical studies including NMR, X-ray crystallographic and footprinting investigations have shown that the primary mode of DNA binding for furamidine is at AT-rich sites of the minor groove. ${ }^{20-27}$ Furthermore, it has been recently clearly shown that furamidine and its analogs enter cells and bind to the nucleus, however their mode of cell penetration has not yet been determined. ${ }^{28}$ A detailed mechanism of antimicrobial action of furamidine and related diamidines has not been elucidated but it remains under investigation. Generally, antimicrobially active molecules of this type show strong affinity for the DNA minor groove, whereas close structural analogs of furamidine (monoamidines) do not significantly bind and are biologically inactive. These results have lead to our working hypothesis that active compounds first form a complex with the minor groove of DNA which leads to inhibition of one or more DNA dependent enzymes or control proteins. Different enzymes in different organisms are thought to be inhibited. ${ }^{22,29-32}$ Another possible mode of action for these type molecules may be direct inhibition of transcription. ${ }^{33,34}$ It seems plausible that these molecules may act by multiple modes. Both the potent and the broad spectrum of activities showed by furamidine and related analogs coupled with their selective minor groove binding has led us to design other groove binders in an effort to discover improved antimicrobial agents.
Despite the fact that both pentamidine and furamidine are highly effective on intravenous administration both have been show to be ineffective on oral administration in animal models. ${ }^{17,19,35,36}$ Development of potent dicationic antimicrobial agents alone is not sufficient to be of public health benefit. Consequently, another major part of our investigation focuses on prodrug approaches for amidines as a means to effectively deliver these potent antimicrobial agents.

\section{Chemistry Results}

\subsection{Synthesis of Furamidine and Analogs}

The synthetic approaches to furamidine and analogs have evolved over the years and they are summarized here. Our original synthesis of furamidine is outlined in Scheme $1^{16}$ and is essentially the approach described by Dann. ${ }^{37}$ The first step involves a Friedel-Crafts reaction between bromobenzene and furmaroyl chloride to form the corresponding dibenzoylethene. The reduction of 1,2-di[4-bromobenzoyl]ethene can be performed by the action of $\mathrm{Zn} / \mathrm{HOAc}$ or stannous chloride; the later is now the preferred reagent. ${ }^{38}$ Furan ring formation is achieved using acetic anhydride $/ \mathrm{H}_{2} \mathrm{SO}_{4}$ which accomplishes the cyclodehydration reaction. 2,5-Bis [4-bromophenyl] furan is converted into 2,5-bis [4-cyanophenyl] furan by the action of copper (I) cyanide in refluxing DMF. The bisnitrile is converted to furamidine by Pinner methodology. ${ }^{16}$ This synthetic route works well on the laboratory scale yet it involves several steps and the first step requires the use of either carbon disulfide or bromobenzene in excess. All of these factors are disadvantageous for large-scale

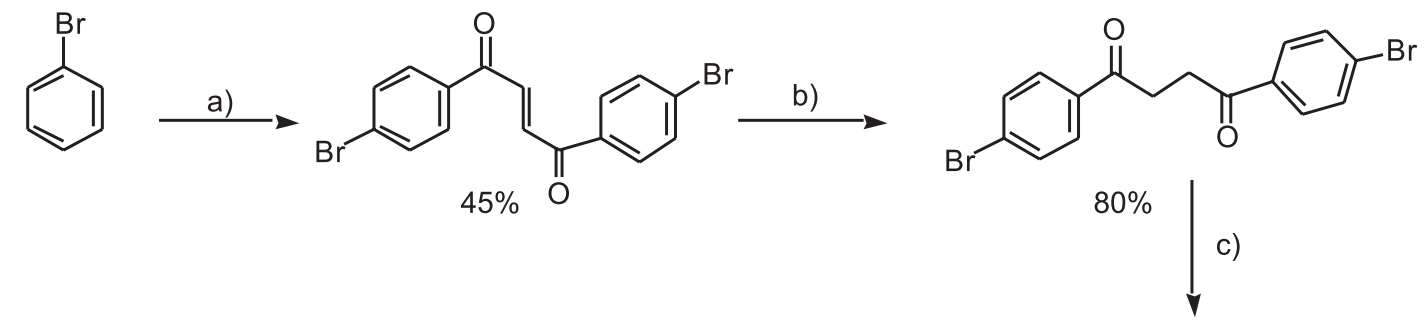<smiles>N=C(N)c1ccc(-c2ccc(-c3ccc(C(=N)N)cc3)o2)cc1</smiles>

a) fumaryl chloride, $\mathrm{AlCl}_{3}, \mathrm{CS}_{2}$ b) $\mathrm{SnCl}_{2}, \mathrm{EtOH}, \mathrm{HOAc}$ c) $\mathrm{Ac}_{2} \mathrm{O}, \mathrm{H}_{2} \mathrm{SO}_{4}$, d) $\mathrm{CuCN}, \mathrm{DMF}$ e) $\mathrm{HCl}, \mathrm{EtOH}$ then $\mathrm{NH}_{3}, \mathrm{EtOH}$ 
synthesis. The key intermediate for preparation of furamidine and analogs is 2,5-bis [4-cyanophenyl] furan and therefore we have explored other synthetic approaches for this compound.

Setter methodology was used to make 2,5-bis [4cyanophenyl] furan as outlined in Scheme 2. In this approach a thiazolium catalyzed reaction of divinyl sulfone and 4-cyanobenzaldehyde gave the saturated 1,4diketone in one step. ${ }^{39}$ Nevertheless, the yield for this reaction was consistently only about $40-50 \%$. Conversion of the saturated 1,4-diketone to the furan was achieved in good yields under similar conditions as noted previously in Scheme 1.

Stille coupling of 2,5-bis[tri-n-butylstannyl]furan with 4-bromobenzonitrile provided a short route to 2,5-bis [4cyanophenyl] furan in an approximately $70 \%$ yield as outlined in Scheme 3. ${ }^{40}$ This route has been used for the scale-up GMP synthesis of a compound which is currently in clinical trials. ${ }^{41}$
Pinner methodology was used for the synthesis of 2,5bis[4(N-alkylamidino)] furans and the structurally related bis-amidoximes directly from 2,5-bis [4-cyanophenyl] furan (Scheme 4). Arguably, the Pinner approach is the most widely used method for preparation of amidines. Although the method generally works quite well, it does require the rigorous exclusion of water. ${ }^{16,19,42}$ A recently described approach for nitrile to amidine conversion involves formation of and subsequent reduction of an amidoxime. ${ }^{43}$ This method does not require rigorous water exclusion and therefore is extremely attractive. Unfortunately, this method is not easily applicable to the preparation of $\mathrm{N}$-alkylamidines.

Scheme 5 outlines our approach for the synthesis of the 2,4-bis[4-amidinophenyl]furans. ${ }^{42}$ The first step involves bromine addition to the 4,4'-bis-cyanochalcone to yield the corresponding dibromo compound. Reaction of excess sodium methoxide with the dibromo analog converts it into an enol ether. Reaction of dimethyl

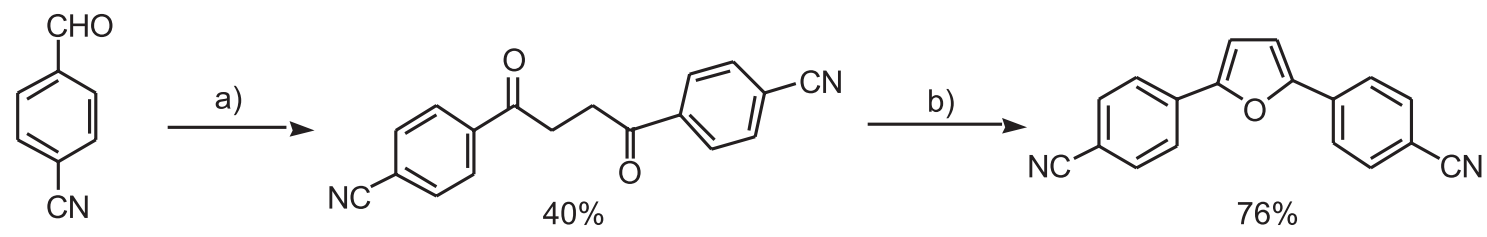

a) divinylsulfone, thiazolium catalyst, $\mathrm{NaOAc}, \mathrm{EtOH}$ b) $\mathrm{Ac}_{2} \mathrm{O}, \mathrm{H}_{2} \mathrm{SO}_{4}$

Scheme 2.

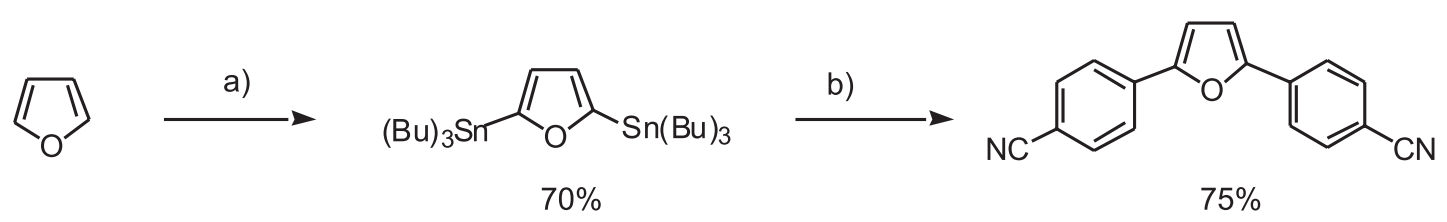

a) BuLi, $(\mathrm{Bu})_{3} \mathrm{SnCl}$ b) 4-bromobenzonitrile, $\mathrm{Pd}\left(\mathrm{PPh}_{3}\right)_{4}$, 1,4-dioxane

Scheme 3.<smiles>CC1CCCCC1CCCCCC#N</smiles>

a) $\mathrm{HCl}, \mathrm{EtOH}$ b) $\mathrm{NHR}$, or $\mathrm{NH}_{2} \mathrm{OR}, \mathrm{EtOH}$<smiles>[R7]NC(=[W])c1ccc(-c2ccc(-c3ccc(C(=[R1])N)cc3)o2)cc1</smiles>

$\mathrm{R}=\mathrm{H}, \mathrm{OH}, \mathrm{OMe} ; \mathrm{R}_{1}=$ various alkyls 
sulfonium ylide (formed in dimethylsulfoxide) with the enol ether yielded 2,4-bis[4-cyanophenyl]furan. An alternative route to the 2,4-bis[phenyl]furan system has been developed more recently. ${ }^{44}$ 2,4-Bis[4cyanophenyl]furan was converted into the desired diamidines using Pinner methodology.

The syntheses of the extended analogs of furamidine 4-6 which incorporate benzimidazole ring systems are outlined in Scheme $6 .{ }^{45}$ In each case the key step of benzimidazole ring formation is achieved by oxidative coupling of an aldehyde with a phenylenediamine. For the synthesis of $\mathbf{4}$ the bis-nitrile was first prepared and then it was converted into the bis-amidine by Pinner methodology. Both 5 and $\mathbf{6}$ were prepared by coupling 3,4-diaminobenzamidine with the appropriate dialdehyde. Benzoquinone was used as the oxidizing agent for each of the coupling reactions and gave the corresponding benzimidazoles in good yields (52-79\%).

\section{Biological Results}

\subsection{Antimicrobial activity of furamidine and its analogs}

Furamidine has been shown to be effective against three different organisms in animal models (Table 1). The effectiveness against trypanosomes was described sometime ago in both murine and simian models. ${ }^{16,17}$ Hall and co-workers ${ }^{36}$ have recently demonstrated that one intravenous dose of $2.5 \mu \mathrm{mol} \mathrm{kg} \mathrm{kg}^{-1}$ of furamidine in a Trypanosomaisis brucei rhodesience mouse model is highly effective (Table 1). A fourteen day intravenous dosing regimen of $13.3 \mu \mathrm{mol} \mathrm{kg} \mathrm{kg}^{-1}$ of furamidine in an immunosuppressed rat model of Pneumocystis carinii pneumonia (PCP) was quite effective as judged by the reduction of lung cyst counts. ${ }^{19}$ When furamidine is given orally in a neonatal mouse model for the gastrointestinal pathogen Cryptosporidium parvum at $33 \mu \mathrm{mol} \mathrm{kg} \mathrm{kg}^{-1}$ for 7 days a significant reduction of cyst counts is observed. ${ }^{18}$

Biophysical investigations ${ }^{46,47}$ have suggested that structural features that increase van der Waals interactions of minor groove binders with the walls of the groove should increase the DNA affinity of these molecules. Although a direct correlation between DNA affinity and antimicrobial effect was not observed, we made a series of bis- $N$-alkyl analogs and evaluated their effectiveness on intravenous injection in the immunosuppressed rat model for $P$. carinii pneumonia. Table 2 contains data for selected compounds from this study. ${ }^{48}$ Most of the $N$-alkyl substituted compounds exhibit a greater DNA affinity than furamidine. The results are consistent with the idea that van der Waals interactions are enhanced by greater surface contact with the walls of the groove. ${ }^{23}$ The biological activity of the<smiles>N#Cc1ccc(C=CC(=O)c2ccc(C#N)cc2)cc1</smiles>

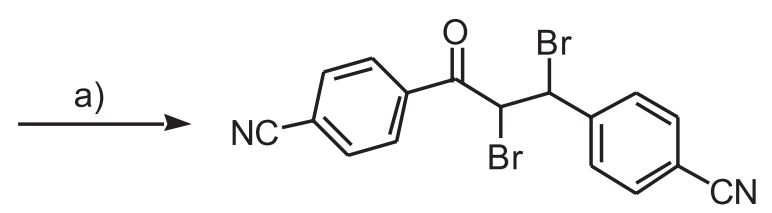

$95 \%$<smiles>[R]NC(=N)c1ccc(-c2coc(-c3ccc(C(=N)N[R])cc3)c2)cc1</smiles><smiles>N#Cc1ccc(-c2coc(-c3ccc(C#N)cc3)c2)cc1</smiles>

a) $\mathrm{Br}_{2}, \mathrm{CHCl}_{3}$ b) $\mathrm{NaOCH}_{3}, \mathrm{CH}_{3} \mathrm{OH}$ c) $\mathrm{NaH}, \mathrm{DMSO}, \mathrm{THF},\left(\mathrm{CH}_{3}\right)_{3} \mathrm{SI}$

d) $\mathrm{HCl}, \mathrm{EtOH}$ then $\mathrm{NH}_{3}$ or $\mathrm{RNH}_{2}$, EtOH 
<smiles>N#Cc1ccc(-c2ccc(C=O)o2)cc1</smiles><smiles>N=C(N)c1ccc2nc(-c3ccc(-c4nc5ccc(C(=N)N)cc5[nH]4)o3)[nH]c2c1</smiles><smiles>N=C(N)c1ccc2nc(-c3ccc(-c4ccc(-c5ccc(-c6nc7ccc(C(=N)N)cc7[nH]6)cc5)o4)cc3)[nH]c2c1</smiles>

a) benzoquinone, EtOH, 3,4-diaminobenzonitrile b) $\mathrm{HCl}$, EtOH then $\mathrm{NH}_{3}$, $\mathrm{EtOH}$ c) benzoquinone, EtOH, 3,4-diaminobenzamidine

\section{Scheme 6.}

more effective compounds in this study range from 10-20 times that of furamidine. Several of these compounds appear to be candidates for further evaluation, however intravenous administration would be required since these compounds are not orally effective.

Our investigations also included the synthesis of $\mathrm{N}$ alkyl substituted analogs of 2,4-bis(4-amidinophenyl) furans. Table 3 contains data for selected compounds from this study. ${ }^{42}$ Comparison of the DNA affinity of the 2,4series to that of their 2,5-isomers shows that the 2,4-analogs exhibit DNA affinities 10-20\% lower than that of the 2,5series. The anti-PCP activity of the 2,4-series is generally somewhat higher and the toxicity is somewhat lower than that of the 2,5-series. The 2,4-diaryl series of diamidines also includes candidates for additional evaluation versus PCP, however these compounds also are not effective on oral administration.

Recently, we made analogs of furamidine with extended aromatic systems which were expected to increase van der Waals interactions and to increase the number of base pairs recognized. The alterations in the furamidine structure included: i) replacement of one phenyl ring by a benzimidazole ring, ii) replacement of both phenyl rings by benzimidazole rings, and iii) addition of benzimidazole

Table 1. In vivo biological activities of furamidine (3)<smiles>N=C(N)c1ccc(-c2ccc(-c3ccc(C(=N)N)cc3)o2)cc1</smiles>

\begin{tabular}{|c|c|c|}
\hline Pathogen(model) & Dosage (Regime) & Results \\
\hline Pneumocystis carinii $(\mathrm{rat})^{a}$ & $13.3 \mu \mathrm{mol} / \mathrm{kg} /$ day (14 day) & $2.1 \%$ untreated control (cysts) \\
\hline Trypanosomaisis brucei rhodesience (mouse) ${ }^{\mathrm{b}}$ & $2.5 \mu \mathrm{mol} / \mathrm{kg} /$ day (1 day) & $6 / 6$ survivors \\
\hline Cryptosporidium parvum (neonatal mouse) $^{c}$ & $33.0 \mu \mathrm{mol} / \mathrm{kg} /$ day (7 day) & $5.1 \%$ untreated control (cysts) \\
\hline
\end{tabular}

${ }^{\mathrm{a}}$ ref. $19 ;{ }^{\mathrm{b}}$ ref. $36 ;{ }^{\mathrm{c}}$ ref. 18. 
Table 2. Biological activities of $N$-alkyl substituted 2,5-bis(4-amidinophenyl)furans vs. Pneumocystis carinii pneumonia in vivo a<smiles>N=C(N)c1ccc(-c2ccc(-c3ccc(C(=N)N)cc3)o2)cc1</smiles>

\begin{tabular}{|c|c|c|c|c|c|}
\hline Compound & $\mathrm{R}$ & $\Delta \mathrm{Tm}($ poly dA-dT) & $\Delta \mathrm{Tm}(\text { oligo })^{\mathrm{b}}$ & Dosage $(\mu \mathrm{mol} / \mathrm{kg})$ & $\%$ of control (cysts of lung tissue) \\
\hline saline & & & & & 100.0 \\
\hline pentamidine & & 12.6 & 4.8 & 22.0 & 2.3 \\
\hline 3 & $\mathrm{H}$ & 25.0 & 11.7 & 2.7 & 5.65 \\
\hline 7 & $\mathrm{i}-\operatorname{Pr}$ & $>28$ & 14.4 & 2.2 & 8.4 \\
\hline 8 & c-pentyl & $>28$ & 15.8 & 0.9 & 0.11 \\
\hline 9 & 2-pentyl & 20.4 & 7.7 & 4.8 & 24.4 \\
\hline
\end{tabular}

${ }^{\mathrm{a}}$ ref. $48 ;{ }^{\mathrm{b}}$ oligo $=\mathrm{d}(\mathrm{CGCGAATTCGCG})_{2}$.

Table 3. Biological activity of $N$-alkyl substituted 2,4-bis(4-amidinophenyl)furans vs. Pneumocystis carinii pneumonia in vivo a

\begin{tabular}{|c|c|c|c|c|c|}
\hline Compound & $\mathrm{R}$ & $\Delta \mathrm{Tm}($ poly dA-dT) & $\Delta \operatorname{Tm}(\text { oligo })^{\mathrm{b}}$ & Dosage $(\mu \mathrm{mol} / \mathrm{kg})$ & $\%$ of control (lung tissue cysts) \\
\hline saline & & & & & 100.0 \\
\hline pentamidine & & 12.6 & 4.8 & 22.0 & 2.3 \\
\hline 3 & & 25.0 & 11.7 & 13.3 & 2.1 \\
\hline 10 & $\mathrm{H}$ & 19.0 & 9.1 & 10.0 & 0.3 \\
\hline 11 & $\mathrm{i}-\mathrm{Pr}$ & 17.6 & 10.9 & 10.0 & 0.04 \\
\hline 12 & c-pentyl & 20.4 & 13.6 & 10.0 & 0.16 \\
\hline
\end{tabular}

${ }^{\mathrm{a}}$ ref. $42 ;{ }^{\mathrm{b}}$ oligo $=\mathrm{d}(\mathrm{CGCGAATTCGCG})_{2}$

rings to the terminal positions of both phenyl rings. ${ }^{45} \mathrm{~A}$ summary of the results for these extended furamidine analogs is included in Table 4. The length of each of these molecules is quite different and it was important to compare the DNA binding of these molecules to oligomers of varying length AT tracts. Table 4 contains comparisons of DNA affinities for furamidine and its three extended analogs 4-6 with three different oligomers containing different numbers of AT base pair binding sites. The disymmetric molecule $\mathbf{4}$ has been found to bind to DNA in an unprecedented dimer motif that offers potential for

Table 4. Values of DNA affinity (DTm) for compounds 3, 4, 5, 6 with oligomers of varying AT sites and in vivo Pneumocystis carinii pneumonia activities ${ }^{\text {a }}$

\begin{tabular}{lcccc}
\hline & $\mathbf{3}$ & $\mathbf{4}$ & $\mathbf{5}$ & $\mathbf{6}$ \\
\hline d(CGCGAATTCGCG) $_{2}$ & 8.3 & 10.0 & 11.7 & $\mathrm{ppt}$ \\
d(CGAAATTTAG) $_{2}$ & 12.6 & 14.1 & 17.1 & -1.5 \\
d(GAAAATTTTCGAAAATTTTC) $_{2}$ & 7.3 & 14.8 & 18.0 & 29.6 \\
\% of control(cyst/g of lung) (PCP) & $2.1^{\mathrm{b}}$ & $51.0^{\mathrm{c}}$ & $1.8^{\mathrm{d}}$ & $180^{\mathrm{e}}$ \\
\hline
\end{tabular}

${ }^{\mathrm{a}}$ ref. $45 ;{ }^{\mathrm{b}} 13.3 \mu \mathrm{mol} / \mathrm{kg} ;{ }^{\mathrm{c}} 5.0 \mu \mathrm{mol} / \mathrm{kg} ;{ }^{\mathrm{d}} 10.0 \mu \mathrm{mol} / \mathrm{kg}$; ${ }^{\text {e }} 7.1 \mu \mathrm{mol} / \mathrm{kg}$. development as a new gene-regulation paradigm. ${ }^{49-51}$ In general, the data shows that as the aromatic stacking surface was extended the DNA binding affinity was increased. On examining the data for d(CGCGAATTCGCG) $)_{2}$ it can be seen that the phenylbenzimidazole $\mathbf{4}$ has greater affinity than furamidine and that the bis-benzimidazole $\mathbf{5}$ has greater affinity than $\mathbf{4}$. The longest molecule $\mathbf{6}$ causes precipitation of the complex. A parallel trend for $\mathbf{3}$ to $\mathbf{4}$ to 5 was noted for the binding to d(CGAAATTTAGC) ${ }_{2}$, however, $\mathbf{6}$ caused a destabilization of the oligomer. The study with d(GAAAATTTTCGAAAATTTTC) ${ }_{2}$, shows that the binding increased with increasing length of the diamidine: $\mathbf{3}<\mathbf{4}<\mathbf{5}<\mathbf{6}$. It seems likely that the behavior of 6 with the two oligomers with the shorter AT-tracts is due to self-stacking interactions being greater than diamidine-DNA interactions. In the system with a binding site large enough to accommodate the entire molecule, eight AT base pairs, these phenomena are not observed. Table 4 also contains the results for the in vivo testing of these compounds vs. PCP. Only the intermediate sized molecule 5 shows significant anti-PCP activity. Extending the length of the compound does not improve the 
antimicrobial efficacy of this particular class of compounds. $^{45}$

We have also studied the replacement of the central five membered furan ring by pyrrole, ${ }^{52}$ thiophene ${ }^{52}$ and other five membered ring units. ${ }^{53}$ The central five membered furan ring has also been replaced by the six member ones pyridine, ${ }^{54}$ pyrimidine,${ }^{55-57}$ pyridazine, ${ }^{53}$ and triazine..$^{58}$ These modifications have led to compounds with both potent DNA affinity and antimicrobial activity, however none appeared to be more advantageous than the furan analogs and a number showed much reduced activity.

In summary we have shown that 2,5-diphenylfuran and 2,4-diphenylfuran diamidines are highly effective antimicrobial agents in several animal models when administered intravenously.

\subsection{Prodrugs for furamidine}

Arylamidines are quite basic and exhibit $\mathrm{pK}$ values of approximately $11,,^{59}$ doubtlessly a significant contributor to the low oral bioavailability of these molecules. Despite the broad spectrum activity of these type molecules few reports have appeared describing prodrug approaches for aryl amidines. ${ }^{60,61}$ Both amidoximes and carbamate derivatives of mono-amidines have been reported to act as prodrugs and have led to improved oral bioavailability for fibrinogen antagonists. ${ }^{60}$ There appears to be no carbamate specific enzymes in mammals, ${ }^{62}$ nevertheless, several alkyl carbamates synthesized from amines have been reported to function as prodrugs. ${ }^{63}$ Reports of prodrugs for diamidines are quite limited. The in vivo conversion of pentamidine dioxime to pentamidine has been reported, ${ }^{35}$ but oral administration of pentamidine diamidoxime in the immunosupressed rat model for PCP was only moderately effective ${ }^{64}$ In contrast, the bis-amidoxime (13) and the bis- $O$-methylamidoxime (14) of furamidine (3) were quite effective against PCP in a rat model on both oral and intravenous administration (see Table 5). ${ }^{65}$

Several carbamates of $\mathbf{3}$ have been prepared as part of our prodrug studies. ${ }^{66}$ Table 5 also includes the data for selected carbamates from this study. Several of these compounds are of comparable effectiveness to the oxime prodrugs in the rat model for $P$. carinii. Two effective prodrug functional groups for furamidine have been developed. One of these prodrugs, 2,5-bis [4(methoxyamidino)phenyl]furan (14), is currently undergoing Phase II clinical trials against African trypanosomiasis. ${ }^{67}$

It is vital to understand the metabolic transformation of $\mathbf{1 4}$ into furamidine (3) for its clinical development as well as to provide fundamental information required to
Table 5. In vivo data vs. Pneumocystis carinii pneumonia for amidoxime and carbamate prodrugs of furamidine

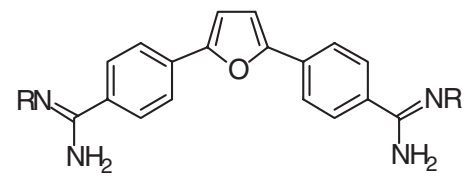

\begin{tabular}{|c|c|c|c|}
\hline \multirow[b]{2}{*}{ Compound } & \multirow[b]{2}{*}{$\mathrm{R}$} & \multicolumn{2}{|c|}{ Cysts/g of Lung } \\
\hline & & $\operatorname{Dose}(\mu \mathrm{mol} / \mathrm{kg})$ & (\% of $\mathrm{Ctrl})$ \\
\hline \multirow[t]{2}{*}{ Pentamidine $^{\mathrm{a}}$} & & i.v. 22.0 & 2.0 \\
\hline & & oral 33.0 & 133.1 \\
\hline \multirow{2}{*}{$\begin{array}{l}\text { Pentamidine } \\
\text { diamidoxime }^{\text {a }}\end{array}$} & & i.v. 22.0 & 0.11 \\
\hline & & oral 33.0 & 17.3 \\
\hline \multirow[t]{2}{*}{$3^{\mathrm{b}}$} & $\mathrm{H}$ & i.v. 13.3 & 0.8 \\
\hline & & oral 39.8 & 44.5 \\
\hline \multirow[t]{2}{*}{$13^{\mathrm{b}}$} & $\mathrm{OH}$ & i.v. 22.0 & 0.7 \\
\hline & & oral 33.0 & 3.1 \\
\hline \multirow[t]{2}{*}{$14^{\mathrm{b}}$} & $\mathrm{OCH}_{3}$ & i.v. 22.0 & 14.3 \\
\hline & & oral 33.0 & 1.8 \\
\hline \multirow[t]{2}{*}{$15^{\mathrm{c}}$} & $\mathrm{COOPh}$ & i.v. 22.0 & 3.6 \\
\hline & & oral 33.0 & 5.7 \\
\hline \multirow[t]{2}{*}{$16^{\mathrm{c}}$} & $\mathrm{COOPh}(p \mathrm{OMe})$ & i.v. 22.0 & 0.02 \\
\hline & & oral 33.0 & 2.1 \\
\hline \multirow[t]{2}{*}{$17^{\mathrm{c}}$} & $\mathrm{COOPh}(p \mathrm{~F})$ & i.v. 22.0 & 0.02 \\
\hline & & oral 33.0 & 2.2 \\
\hline
\end{tabular}

${ }^{\mathrm{a}}$ ref. $64 ;{ }^{\mathrm{b}}$ ref. $65 ;{ }^{\mathrm{c}}$ ref. 66.

aid in the development of new amidine prodrugs. Detailed studies of the metabolism of $\mathbf{1 4}$ are ongoing. ${ }^{38,68-70}$ Preliminary results indicate that the metabolism pathway is a multistep one. The key first step in the process appears to be demethylation of the methoxime to form an amidoxime. The amidoxime appears to be the functional group that is reduced to form the amidino group. ${ }^{68,69}$ Since two bioconversion steps are required to activate $\mathbf{1 4}$ it appears to be a double prodrug.

\section{Conclusions}

The more active compounds from both the 2,5-bis [4$\mathrm{N}$-alkylamidinophenyl)furan and 2,4-bis (4amidinophenyl)furan series showed increased efficacy and lower toxicity compared to pentamidine and furamidine on intravenous administration in the immunosupressed rat model for $P$. carinii. However, these compounds are not effective when given orally. The furamidine analogs with extended aromatic systems are generally less effective and more toxic than furamidine. Diamidoxime and dicarbamate derivatives of furamidine, effective on oral administration in the immunosupressed rat model for P. carinii, 
demonstrate the potential of the prodrug approach to effectively deliver these potent antimicrobial DNA minor groove binding agents. One of these compounds is currently in Phase II clinical trials.

\section{Acknowledgments}

This work was supported by awards from NIH (Grants NIAID RO1AI 46365, RO1GM61587, and R44 AI4051802), Immtech International, Inc. and the Bill and Melinda Gates Foundation. Without the numerous creative contributions of biological collaborators, students and postdoctoral associates, whose names appear on many of the references cited, this work would not have progressed. The introduction to the potential of diaryl diamidines as antimicrobial agents by Dr. Edgar A. Steck is gratefully acknowledged. I am particularly indebted to Professors W. David Wilson, Richard R. Tidwell and James E. Hall for many years of rewarding collaboration.

\section{References}

1. Fox, K. R.; Sansom, C. E.; Stevens, M. P. G.; FEBS Lett. 1990, 266, 150.

2. Edwards, K.J.; Jenkins, T. C.; Neidle, S.; Biochemistry 1992, 31, 7104.

3. Brown, D.G.; Sanderson, M. R.; Skelly, J. V.; Jenkins, T.C.; Brown, T.; Garman, E.; Stuart, D. I.; Neidle, S.; EMBO J. 1990, 9, 1329.

4. Brown, D.G.; Sanderson, M. R.; Garman, E.; Neidle, S.; J. Mol. Biol. 1992, 226, 481.

5. Greenhill, J. V.; Lue, P.; Prog. Med. Chem. 1993, 30, 203.

6. King, H.; Lourie, E.; Yorke, W.; Ann. Trop. Med. Parasitol. 1938, 32, 177.

7. Lourie, E. M.; Yorke, W.; Ann. Trop. Med. Parasitol. 1939, 33, 289.

8. Tidwell, R.R.; Boykin, D. W. In Small Molecule DNA and RNA Binders: From Synthesis to Nucleic Acid Complexes; Demeunynck, M.; Bailly, C.; Wilson, W. D., eds., Wiley-VCH: New York, in press

9. Apted, F. I. C.; Pharmacol. Ther. 1980, 11, 391.

10. Bryceson, A. D. M.; Chulay, J. D.; Mugambi, M.; Were, J. B.; Gachihi, G.; Chunge, C. N.; MuIgai, R.; Bhatt, S. M.; Ho, M.; Spencer, H. C.; Meme, J.; Anabwani, G.; Trans. Roy. Soc. Trop. Med. Hyg. 1985, 79, 705.

11. Hughes, W. T.; McNabb, P. C.; Makres, T. D.; Feldman, S.; Antimicrob. Agents Chemother. 1974, 5, 289.

12. Tidwell, R.R.; Bell, C.A. In Pentamidine and Related Compounds in the Treatment of Pneumocystis carinii Infection in Pneumocystis carninii, P. Walzer, ed., Marcel Decker: New York, 1993, p. 561.
13. Goa, K.; Campoli-Richards, D.M.; Drugs, 1987, 33, 332.

14. Drake, S.; Lampasona, V., Nicks, H.L., Scharzmann, S.W.; Clin. Pharmacol., 1985, 4, 507.

15. Berger, B.; Naiman, N.A.; Hall, J.E.; Peggins, J.; Brewer, T.G.; Tidwell, R.R.; Antimicrob. Agents Chemother. 1992, 36, 1825.

16. Das, B. P.; Boykin, D. W.; J. Med. Chem. 1976, 20, 531.

17. Steck, E.A.; Kinnamon, K.E., Davidson, DE, Duxbury, R.E., Johnson, A.J.; Masters, R. E.; Experimential Parasitology, 1982, 3,133 .

18. Blagburn, B.L.; Drain, K.L., Land, T.M., Moore, P.H., Lindsay, D.S., Kumar, A., Shi, J., Boykin, DW, Tidwell, R.R.; J. Parasitol. 1998, 84, 851.

19. Boykin, D. W.; Kumar, A.; Spychala, J.; Zhou, M.; Lombardy, R. J.; Wilson, W. D.; Dykstra, C. C.; Jones, S. K.; Hall, J. E.; Tidwell, R. R.; Laughton, C.; Nunn, C. M.; Neidle, S.; J. Med. Chem. 1995, 38, 912.

20. Tanious, F. A.; Spychala, J.; Kumar, A.; Greene, K.; Boykin, D. W.; Wilson, W. D.; J. Biomol. Struct. Dyn. 1994, 11, 1063.

21. Wilson, W. D.; Tanious, F.; Ding, D.; Kumar, A.; Boykin, D. W.; Colson, P.; Houssier, C.; Bailly, C.; J. Am. Chem. Soc. 1998, 120, 10310.

22. Bailly, C.; Dassonneville, L.; Carrascol, C.; Lucasl, D.; Kumar, A.; Boykin, D. W.; Wilson, W. D.; Anti-Cancer Drug Design, 1999, 14, 47.

23. Mazur, S.; Tanious, F.; Ding, D.; Kumar, A.; Boykin, D. W.; Neidle, S.; Wilson, W. D.; J. Mol. Biol. 2000, 300, 321.

24. Trent, J. O.; Clark, G. R.; Kumar, A.; Wilson, W. D.; Boykin, D. W.; Hall, J. E.; Tidwell, R. R.; Blagburn, B. L.; Neidle, S.; J. Med. Chem. 1996, 36, 4554.

25. Guerri, A.; Simpson, I. J.; Neidle, S.; Nucleic Acids Res. 1998, $26,2873$.

26. Laughton, C. A.; Tanious, F.; Nunn, C. M.; Boykin, D. W.; Wilson, W. D.; Neidle, S.; Biochemistry, 1996, 35, 5655.

27. Simpson, J.; Lee, M, ; Kumar, A.; Boykin, D.W.; Neidle, S.; Bioorg. Med. Chem. Lett. 2000, 10, 2593.

28. Lansiaux, A.; Dassoneville, L.; Facompre, M.; Kumar, A.; Stephens, C.E.; M. Bajic, M. F. Tanious, F.; Wilson, D. W.; Boykin, D. W.; Bailly, C.; J. Med. Chem. 2002, 45, 1994.

29. Bell, C. A.; Dykstra, C. C.; Naiman, N. N.; Cory, M.; Fairley, T. A.Tidwell, R. R.; Antimicrob. Agents Chemother. 1993, 37, 2668 .

30. Hildebrandt, E. F.; Boykin, D. W.; Tidwell, R. R.Dykstra, C. C.; J. Eukaryotic Microbiol. 1998, 45, 112.

31. Beerman, T. A.; McHugh, M. M.; Sigmund, R.; Lown, J. W.; Rao, K. E.; Bathini, R.; Biochim. Biophys. Acta 1992, 1131, 52.

32. Dykstra, C. C.; McClernon, D. R.; Elwell, L. P.; Tidwell, R. R.; Antimicrob. Agents Chemother. 1994, 38, 1890.

33. Henderson, D.; Hurley, L. H.; Nature Medicine 1995, 1, 525.

34. Fitzgerald, D. J.; Anderson, J. N.; J. Biol. Chem. 1999, 274, 27128. 
35. Clement, B.; Immel, M.; Terlinden, R.Wingen, F.-J.; Arch. Pharm. (Weinheim) 1992, 325, 61.

36. Hall, J.E. unpublished results.

37. Dann, O.; Fick, H.; Pietzner, B.; Walkenhorst, E.; Fernbach, R.; Zeh, D.; Liebigs Ann. Chem. 1975, 160.

38. Stephens, C.E.; Patrick, D.A.; Chen, H.; Tidwell, R.R.; Boykin, D. W.; J. Labelled Cpd. Radiopharm. 2001, 44, 197.

39. Bajic, M.; Kumar, A.; . Boykin, D. W.; Heterocyclic Comm., 1996, 2, 135.

40. Kumar, A.; Stephens C.E.; Boykin, D.W.; Heterocyclic Comm. 1999, 5, 301.

41. McChesney-Harris, L.; Allen, J.; Tidwell. R.R.; Schure, R.; Zhao, L.; Thurmond, J.; Boulas, R.; Fallon. A.; Holt, K.; Schutte, L.; Stowell, G.; Potts, B.; Labeda, J.; ICAAC Annual Meeting; Chicago, USA, December 2001.

42. Francesconi, I.; Wilson, W. D.; Tanious, F. A.; Hall, J. E.; Bender, B. K.; McCurdy, D. R.; Tidwell, R. R.; Boykin, D. W.; J. Med. Chem. 1999, 42, 2260.

43. Judkins, B.D.; Allen, D.G.; Cook, T. A.; Evans, B.; Sardharwala, T. E.; Syn. Comm. 1996, 26, 4351.

44. Francesconi, I.; Patel, A.; Boykin, D. W.; Synthesis, 1999, 61.

45. Hopkins, K.; Kumar, A.; Bajic, M.; Wilson, W.D.; Bender, B.C.; McCurdy, D.R.; Hall, J.E.; Tidwell, R.R.; Boykin, D.W.; J. Med. Chem. 1998, 41, 3872.

46. Czarny, A.; Boykin, D.W.; Wood, A.A.; Nunn, C.M.; Neidle, S.; Zhao, M.; Wilson, W.D.; J. Am. Chem. Soc. 1995, 117, 4716.

47. Sauers, R. R.; Bioorg. Med. Chem. Lett. 1995, 5, 2573.

48. Boykin, D. W.; Kumar, A.; Xiao, G.; Wilson, W. D.; Bender, B. C.; McCurdy, D.R.; Hall, J. E.; Tidwell, R. R.; J. Med. Chem. 1998, 41, 124.

49. Wang, L.; Bailly, C.; Kumar, A.; Ding, D.; Bajic, M.; Boykin, D. W.; Wilson, W. D.; Proc. Natl. Acad. Sci. U S A. 2000, 97, 12.

50. Wang, L.; Carrasco, C.; Kumar, , A.; Stephens, C. E.; Bailly, C.; Boykin D. W.: Wilson, W. D.; Biochemistry 2001, 40, 2511.

51. Bailly, C. Tardy, C.; Wang, L.; Armitage, B.; Hopkins, K.; Kumar, A.; Schuster, G.B.; Boykin, D. W.; Wilson, W.D.; Biochemistry 2001 40, 9770.49?

52. Das, B. P.; Boykin, D.W.; J. Med. Chem. 1977, 20, 1219.

53. Das, B.P.; Wallace, R. A.; D.W. Boykin., D. W.; J. Med. Chem. 1980, 23, 578.

54. Kumar, A.; Rhodes, R.A.; Spychala, J.; Wilson, W.D.; Boykin, D.W.; Tidwell, R. R.; Dykstra, C.C.; Hall, J.E.; Jones S.K.; Schinazi, R.F.; Eur. J. Med. Chem. 1995, 30, 99.

55. Kumar, A.; Zhao, M.; Wilson, W. D.; D.W. Boykin, D.W.; Bioorg. Med. Chem. Letters, 1994, 4, 2913.
56. Kumar, A.; Boykin, D.W.; Wilson, W.D.; Jones, S.K.; Bender, B.K.; Dykstra, C.C.; Hall, J.E.; Tidwell, R. R.; Eur. J. Med. Chem. 1996, 31, 767.

57. Boykin, D.W.; Kumar, A.; Bajic, M.; Wilson, W. D.; Bender, B.K.; Hall, J.E.; Tidwell, R.R.; Eur. J. Med. Chem. 1997, 32, 965.

58. Spychala, J.; Wilson, W.D.; Boykin, D.W.; Tidwell, R.R.; Dykstra, C.C.; Hall, J.E.; Jones, S.K.; Schinazi, R.F.; Eur. J. Med. Chem. 1994, 29, 363.

59. Oszczapowicz, J. In The Chemistry of Amidines and Imidates; S. Patai, Z.R., ed., John Wiley \& Sons Ltd: London, 1991, vol.2, p. 623.

60. Weller, T.; Alieg, L.; Beresini, M.; Blackburn, B.; Bunting, S.; Hadvary, P.; Muller, M.H.; Knopp, D.; Levet-Trafit, B.; Lipari, M.T.; Modi, N.B.; Muller.; Refino, C.J.; Schmitt, M.; Schonholzer, P.; Weiss, S.; Steiner, B.; J. Med. Chem. 1996, 39, 3139.

61 Shahrokh, Z.; Lee, E.; Olivero, A.G.; Matamoros, R.A.; Roborage, K.D.; Lee, A.; Weise, K.J.; Blackburn, B.K.; Powell, M.F.; Pharm. Res. 1998, 15, 434.

62. Verbiscar, A.J.; Abood, L.G.; J. Med. Chem. 1970, 13, 1176.

63. Alexander, J.; Cargill, R.; Michelson, S.R.; Schwam, H.; J. Med. Chem. 1988, 31, 318.

64. Hall, J.E.; Kerrigan, J.E.; Ramachandran, K.; Bender, B.C.; Stanko, J.P.; J ones, S.K.; Patrick, D.A.; Tidwell, R.R.; Antimicrob. Agents Chemother. 1998, 42, 666.

65. Boykin, D.W.; Kumar, A.; Bender, B.K.; Hall, J. E.; Tidwell, R. R.; Bioorg Med. Chem. Lett. 1996, 6, 3017.

66. Rahmathullah, S. M.; Hall, J. E.; Brender, B. K.; . McCurdy, D. R.; Tidwell, R. R.; Boykin. D W.; J. Med. Chem. 1999, 42, 3994.

67. Yeramanian, P.; Kruse, M.; Allen, J.; McChesney-Harris, L.; Trendler, K.; Hall, J. E.; Tidwell. R.R.; ICAAC Annual Meeting; Chicago, USA, December 2001.

68. Zhou, L.; Ph.D. Thesis, University of North Carolina at Chapel Hill, USA, 2002.

69. Zhou, L.; Voyksner, R.D.; Stephens, C. E.; Anbazhagen, M.; . Boykin, D. W.; Hall, J. E.; Tidwell, R. R.; Rapid Comm. Mass Spectroscopy, 2002, 16, 1078.

70. Allen, J.; Ndungu, J.; Mdachi, R.; Ngotho, J.; Brun, R.; Yeramanin, P.; Burri, C.; McChesney-Harris, L.; Trendler, K.; John, B.; Midgley, I.; Hall, J. E.; Tidwell. R.R.; ICAAC Annual Meeting; Chicago, USA, December 2001.

Received: April 11, 2002 Published on the web: November 22, 2002 